\title{
EXPERIMENTAL INVESTIGATION OF POST-DRYOUT HEAT TRANSFER IN AN ANNULUS WITH SPACERS
}

\author{
Per Persson*, Stellan Hedberg* and Henryk Anglart ${ }^{\circ}$ \\ *Royal Institute of Technology, Brinellv 60, 100-44 Stockholm, E-mail: perper@energy.kth.se \\ 'Royal Institute of Technology, Brinellv 60, 100-44 Stockholm, E-mail: henryk@energy.kth.se
}

\begin{abstract}
Experimental investigation of the post-dryout heat transfer in annulus test section has been performed in the high-pressure two-phase loop at the Royal Institute of Technology (KTH), Nuclear Reactor Technology division. The test section has an annular geometry with $10 \mathrm{~mm}$ rod outer diameter and $22.1 \mathrm{~mm}$ tube inner diameter. Seven spacers are located along the test section to keep the rod and the tube equidistant along the test section. Both the tube and the rod are manufactured of Inconel 600 to withstand high temperatures. The experiments indicate a very strong influence of spacers on post-dryout heat transfer. In particular, for several cases with relatively low local quality the dryout spot was limited to a direct proximity (upstream) of spacers. Only for relatively high powers the dryout patch could cover the whole distance between two neighboring spacers. For low mass flow rates dryout and post-dryout occurred near the test section outlet. With increasing mass flow rates the location of the dryout spot moved upstream of the upper-most spacer, for the cases when dryout occurred on the outer tube. The present experimental data give a new insight into the mechanism of dryout occurrence in annuli with spacers as well as indicate a strong ability of spacers to quench dryout spots and enhance the heat-transfer coefficient in the postdryout heat transfer regime.
\end{abstract}

\section{INTRODUCTION}

Understanding of the Post-dryout heat transfer mechanism is very important in evaluation of safety aspects of Boiling Water Reactors (BWR). This type of heat transfer is not allowed under normal operating conditions of BWRs, however, it may appear in some off-normal (steady-state or transient) situations. In such cases it is essential to be able to predict the maximum clad temperature as well as time history of the temperature distribution, since they determine the risk of the loss of integrity of the cladding.

Therefore, a grate amount of research has been devoted to study the post-dryout heat transfer, including both the experimental and the analytical work. The present study is a continuation of previous experiments on dryout and postdryout performed in the same loop [1-3].

\section{EXPERIMENTAL PROCEDURE}

\section{Experimental set-up}

The measurements were made on a two-phase loop shown in Fig. 1.
Thermal-hydraulic two-phase flow loop

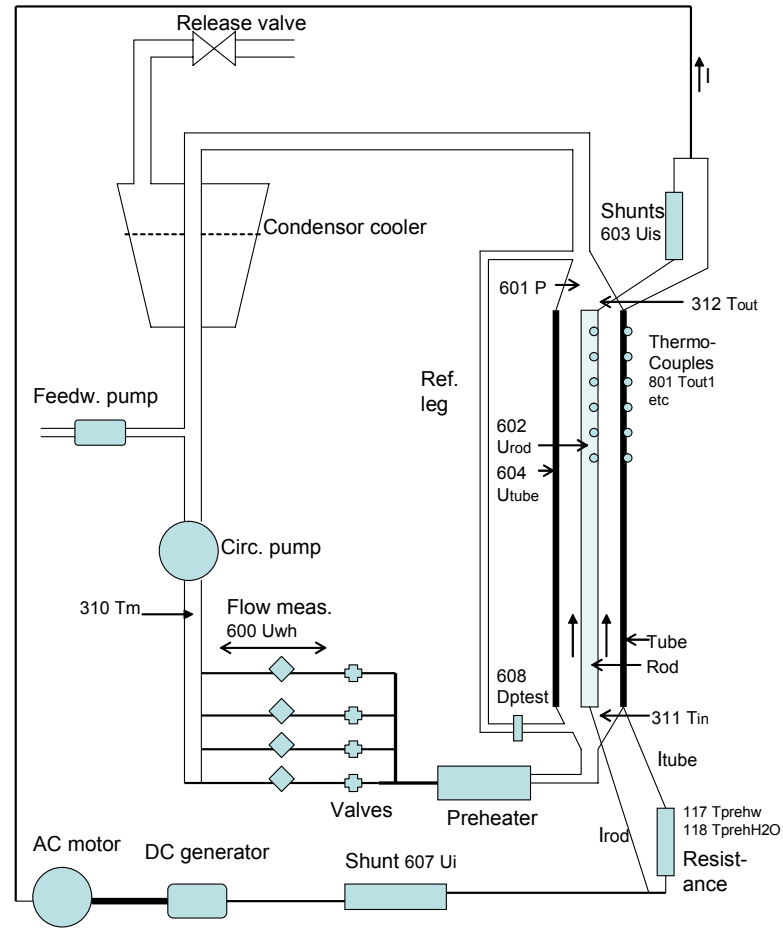

(The numbers attached to the signals are those used in the computer program)

Figure 1. Two-phase flow loop used in experiments.

The test section, made of inconel 600 rod and tube, had an annular geometry of 3650x22.1x10 mm, as shown in Fig. 2. 


\section{()}

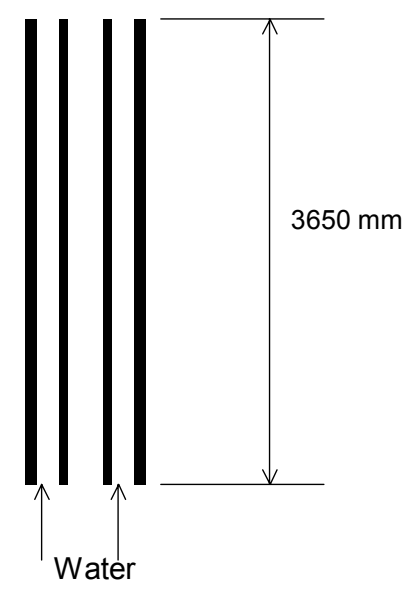

Figure 2. Test section.

The central rod was kept at the centre of annulus by means of 7 spacers, as shown in Fig. 3.

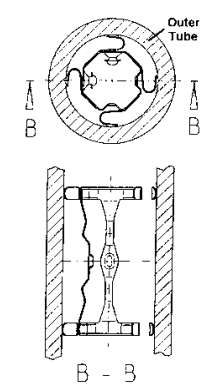

Figure 3. Spacer design and arrangement in the test section.

\section{Measurement technique}

For each measurement the operating conditions were set around the required inlet temperature, mass flux and system pressure. The heat flux in the annulus was set to a value which was known to be just below the dryout occurrence. Next, the total power was gradually increase to obtain dryout and eventually to stabilize post-dryout condition in the test section. The rod and tube temperature were measured at several axial locations, as shown in Fig. 4. Relative location of thermocouples against spacer positions is indicated as well.

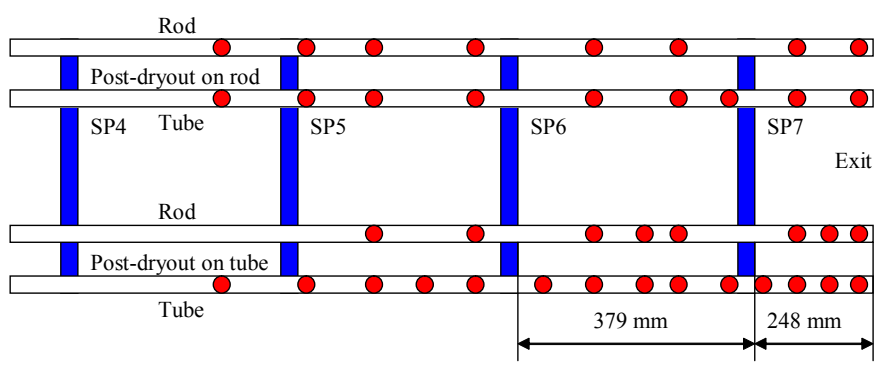

Figure 4. Axial locations of thermocouples.
Due to a limited space inside the heated rod, only 8 thermocouples could be installed. There was no such restriction on the tube wall and 14 thermocouples were installed. The axial locations of thermocouples are shown in Table 1. As can be seen, the thermocouple positions were selected in different ways depending whether the post-dryout measurements were performed for the tube or the rod wall.

Table 1. Thermocouple axial locations

\begin{tabular}{|c|c|c|c|c|}
\hline \multirow{2}{*}{$\begin{array}{c}\text { Distance } \\
\text { from } \\
\text { inlet } \\
{[\mathrm{mm}]}\end{array}$} & \multicolumn{2}{|c|}{$\begin{array}{l}\text { Rod wall } \\
\text { thermocouple }\end{array}$} & \multicolumn{2}{|c|}{$\begin{array}{l}\text { Tube wall } \\
\text { thermocouple }\end{array}$} \\
\hline & $\begin{array}{c}\mathrm{PDO} \\
\text { rod }\end{array}$ & $\begin{array}{l}\text { PDO } \\
\text { tube }\end{array}$ & $\begin{array}{c}\text { PDO } \\
\text { rod }\end{array}$ & $\begin{array}{c}\text { PDO } \\
\text { tube }\end{array}$ \\
\hline 2500 & TCR1 & TCT1 & & TCT1 \\
\hline 2650 & TCR2 & TCT2 & & TCT2 \\
\hline 2800 & TCR3 & TCT3 & TCR3 & TCT3 \\
\hline 2870 & & & & TCT4 \\
\hline 2950 & TCR5 & TCT5 & TCR5 & TCT5 \\
\hline 3050 & & & & TCT6 \\
\hline 3150 & TCR7 & ТCT7 & TCR7 & TCT7 \\
\hline 3220 & & & TCR8 & TCT8 \\
\hline 3300 & TCR9 & TCT9 & TCR9 & TCT9 \\
\hline 3365 & & TCT10 & & TCT10 \\
\hline 3400 & & & & TCT11 \\
\hline 3450 & TCR1 & ТCT12 & TCR1 & TCT12 \\
\hline 3520 & & & TCR1 & TCT13 \\
\hline 3600 & TCR1 & TCT14 & TCR1 & TCT14 \\
\hline
\end{tabular}

\section{RESULTS OF MEASUREMENTS}

The measurements were performed for 70 bar pressure and for two values of the inlet subcooling: 10 and $40 \mathrm{~K}$. The mass flux was varied from 500 to $2000 \mathrm{~kg} \mathrm{~m}^{-2} \mathrm{~s}^{-1}$. The uniform axial power distribution was applied in all runs, whereas the lateral power distribution was set such that the dryout occurred either on the rod or on the tube wall. When heat fluxes on both walls were equal to each other, dryout occurred on the rod wall. Dryout shifted to the outer (tube) wall only when the heat flux was approximately $50 \%$ higher on that wall compared to the heat flux on the rod wall.

\section{Post-dryout occurrence on the rod wall}

In the present test section with the actual spacer positions, dryout always occured at the exit part of the test section. When the power was increased, for lower mass velocities, the wall temperature became highest in the exit region. For higher mass velocities, higher than about $1000 \mathrm{~kg} \mathrm{~m}^{-2} \mathrm{~s}^{-1}$, the highest wall temperature occurred upstream of the upper spacer (spacer $\mathrm{Nr} 7$ ). Figures 5 through 17 show the rod wall temperature increase at the inner surface (thermocouple location) along the channel.

The spacers had a strong influence on the wall temperature such that the temperature just downstream a spacer the postdryout temperature rise either disappears completely or is reduced to a considerably lower level than upstream the spacer.

In some cases post-dryout occurred at three different locations simultaneously, at the exit and just below the upper and second upper spacers. In between these positions the post-dryout patch was quenched by the spacers such that the temperatures downstream the spacers were not elevated. 


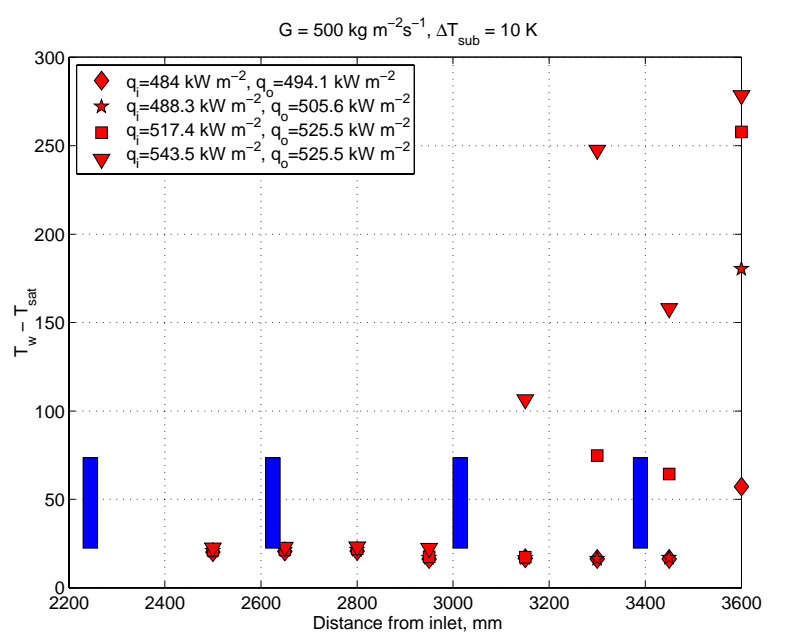

Figure 5. Rod wall temperature increase for $\mathrm{G}=500 \mathrm{~kg} \mathrm{~m}^{-2} \mathrm{~s}^{-1}$, $p=70$ bar and inlet subcooling $10 \mathrm{~K}$.

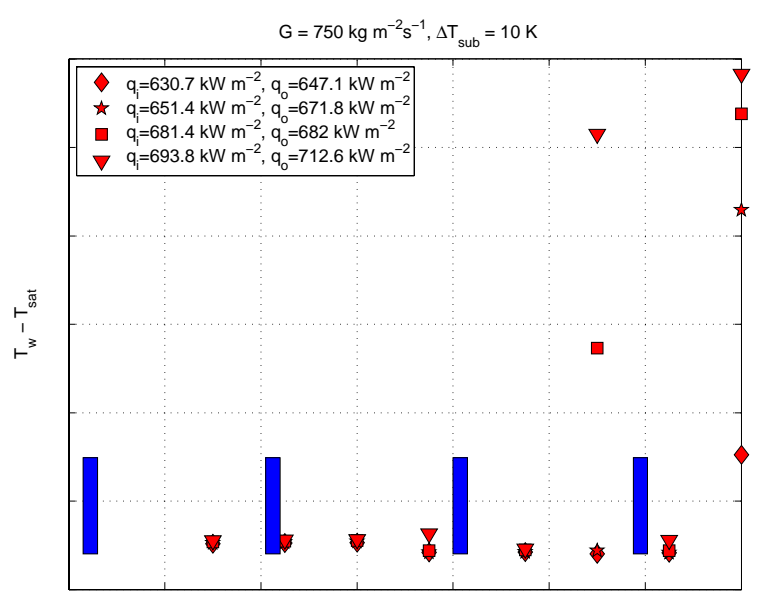

Distance from inlet, $\mathrm{mm}$

Figure 6. Rod wall temperature increase for $\mathrm{G}=750 \mathrm{~kg} \mathrm{~m}^{-2} \mathrm{~s}^{-1}$, $p=70$ bar and inlet subcooling $10 \mathrm{~K}$.

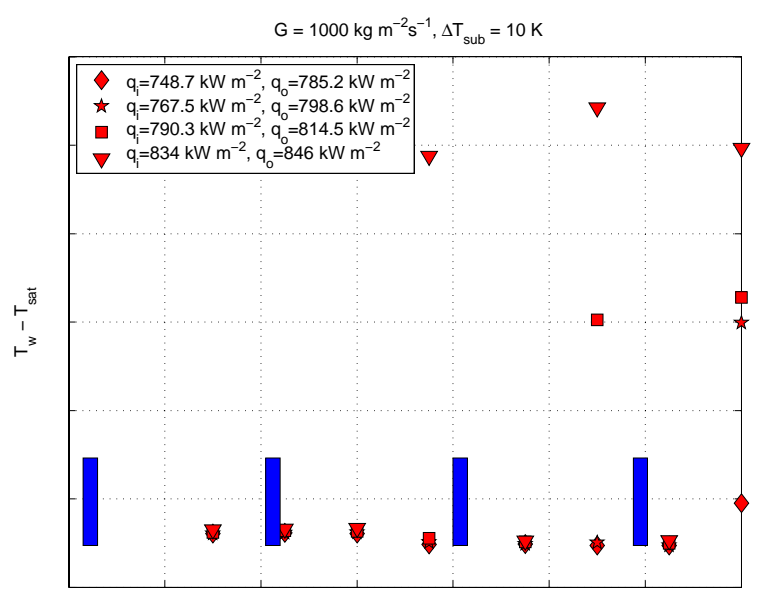

Distance from inlet, $\mathrm{mm}$

Figure 7. Rod wall temperature increase for $\mathrm{G}=1000 \mathrm{~kg} \mathrm{~m}^{-2} \mathrm{~s}^{-1}$, $p=70$ bar and inlet subcooling $10 \mathrm{~K}$.

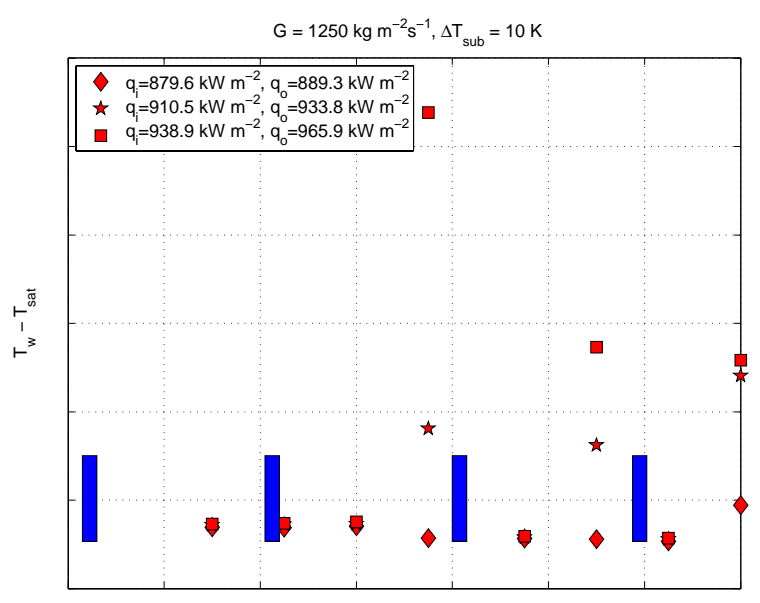

Distance from inlet, $\mathrm{mm}$

Figure 8. Rod wall temperature increase for $G=1250 \mathrm{~kg} \mathrm{~m}^{-2} \mathrm{~s}^{-1}$, $\mathrm{p}=70$ bar and inlet subcooling $10 \mathrm{~K}$.

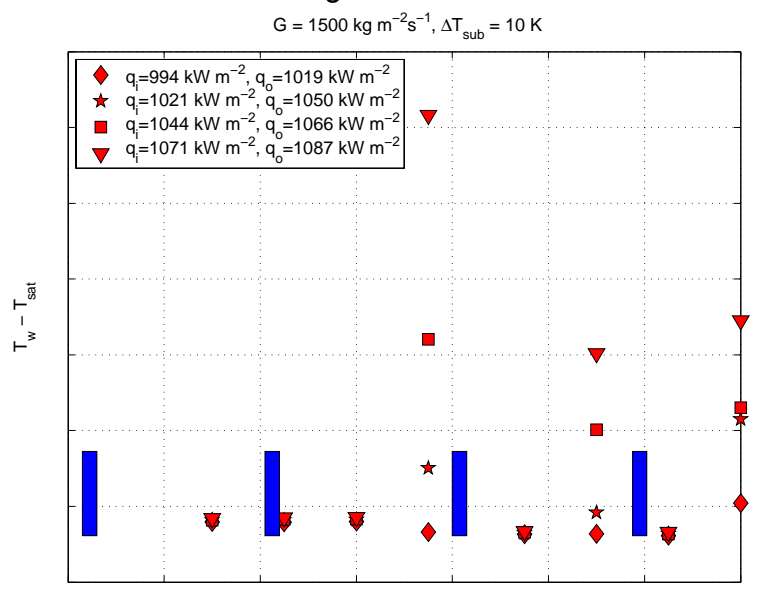

Distance from inlet, $\mathrm{mm}$

Figure 9. Rod wall temperature increase for $\mathrm{G}=1500 \mathrm{~kg} \mathrm{~m}^{-2} \mathrm{~s}^{-1}$, $p=70$ bar and inlet subcooling $10 \mathrm{~K}$.

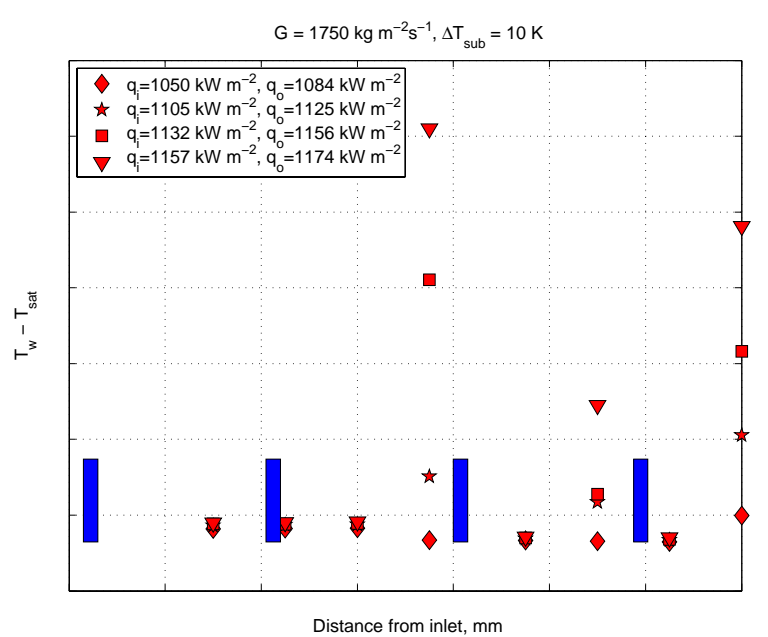

Figure 10. Rod wall temperature increase for $\mathrm{G}=1750 \mathrm{~kg} \mathrm{~m}^{-2} \mathrm{~s}^{-}$ ${ }_{1}, \mathrm{p}=70$ bar and inlet subcooling $10 \mathrm{~K}$. 


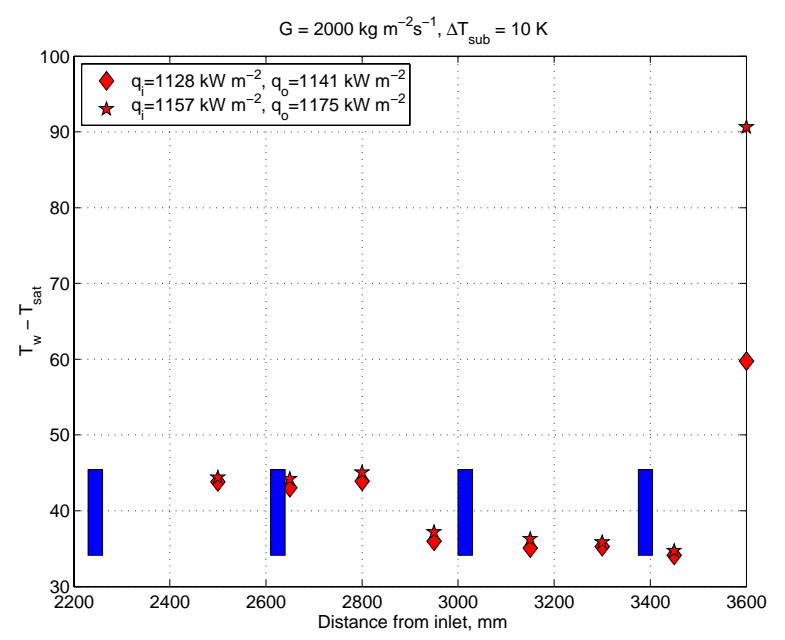

Figure 11. Rod wall temperature increase for $G=2000 \mathrm{~kg} \mathrm{~m}^{-2} \mathrm{~s}$ ${ }^{1}, \mathrm{p}=70$ bar and inlet subcooling $10 \mathrm{~K}$.

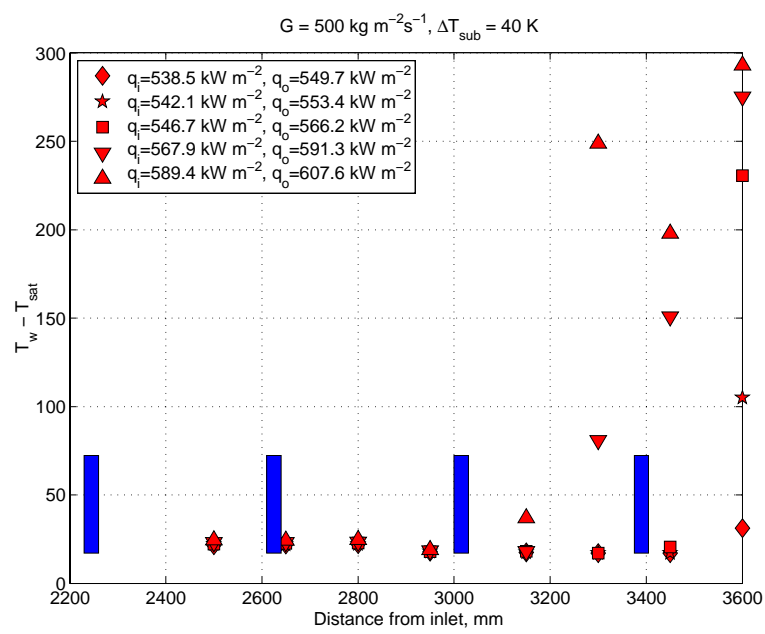

Figure 12. Rod wall temperature increase for $\mathrm{G}=500 \mathrm{~kg} \mathrm{~m}^{-2} \mathrm{~s}$ $1, p=70$ bar and inlet subcooling $40 \mathrm{~K}$.

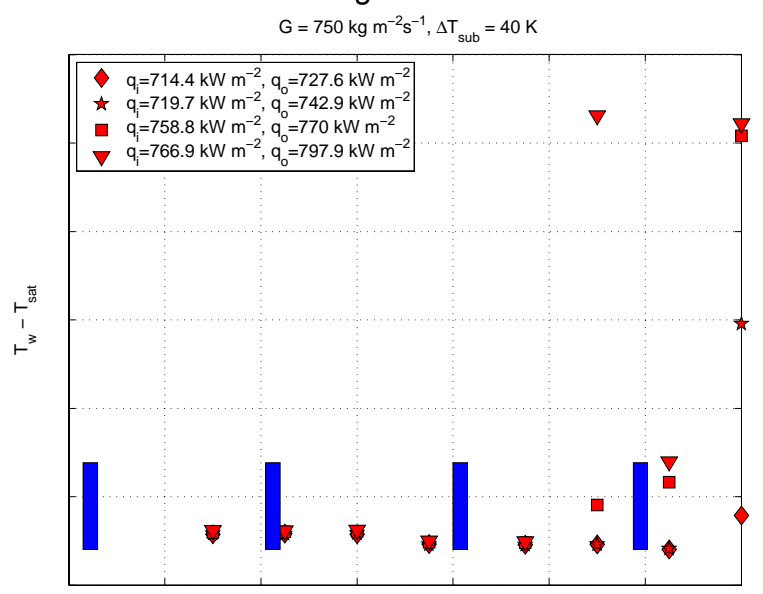

Distance from inlet, $\mathrm{mm}$

Figure 13. Rod wall temperature increase for $\mathrm{G}=750 \mathrm{~kg} \mathrm{~m}^{-2} \mathrm{~s}^{-1}$, $p=70$ bar and inlet subcooling $40 \mathrm{~K}$.

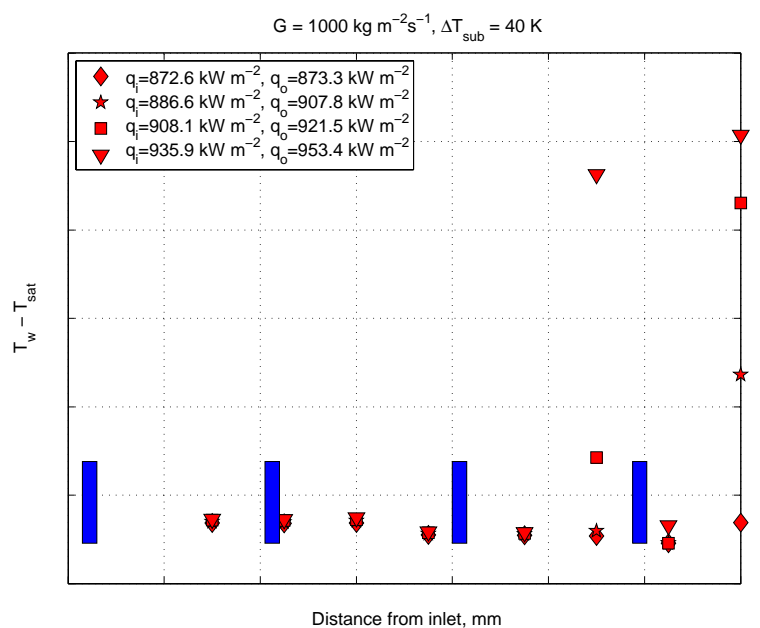

Distance from inlet, $\mathrm{mm}$

Figure 14. Rod wall temperature increase for $G=1000 \mathrm{~kg} \mathrm{~m}^{-2} \mathrm{~s}^{-}$ 1, $\mathrm{p}=70$ bar and inlet subcooling $40 \mathrm{~K}$.

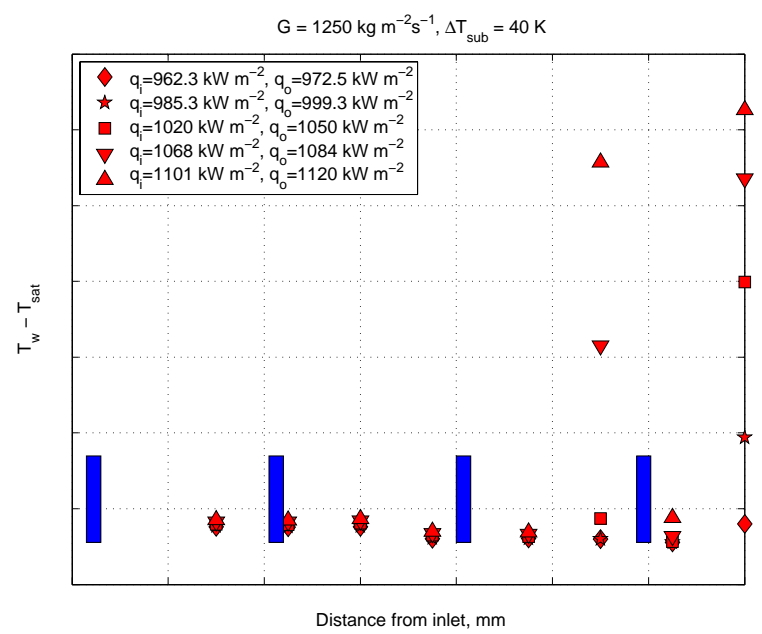

Figure 15. Rod wall temperature increase for $G=1250 \mathrm{~kg} \mathrm{~m}^{-2} \mathrm{~s}^{-}$ ${ }^{1}, \mathrm{p}=70$ bar and inlet subcooling $40 \mathrm{~K}$.

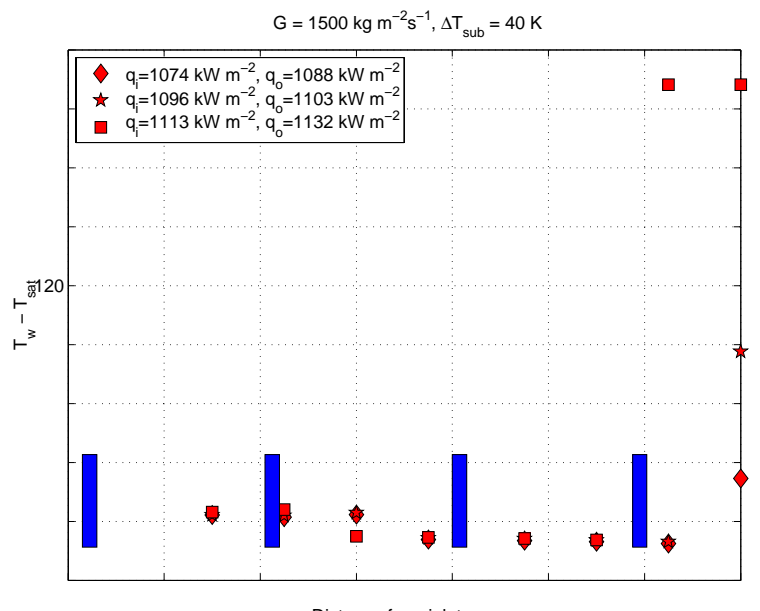

Distance from inlet, $\mathrm{mm}$

Figure 16. Rod wall temperature increase for $\mathrm{G}=1500 \mathrm{~kg} \mathrm{~m}^{-2} \mathrm{~s}$ ${ }^{1}, \mathrm{p}=70$ bar and inlet subcooling $40 \mathrm{~K}$. 


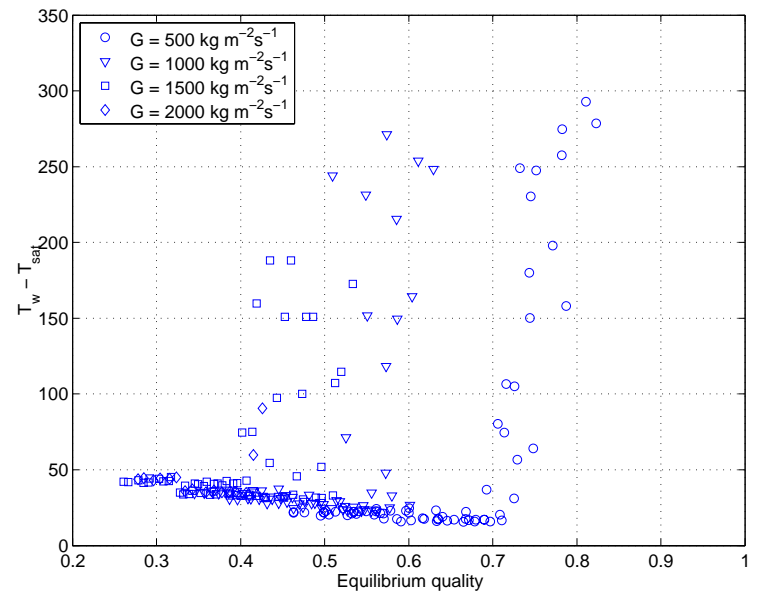

Figure 17. Rod wall temperature increase versus local equilibrium quality.

\section{Post-dryout occurrence on the tube wall}

For lower mass velocities, as for the rod, post-dryout started at the exit part of the tube and the wall temperature increased with power. However, for higher mass velocities, higher than about $1000 \mathrm{~kg} \mathrm{~m}^{-2} \mathrm{~s}^{-1}$ the post-dryout moved to just downstream the upper spacer and wall was quenched at the exit.

The measured wall temperature increase versus distance for several mass flux values are shown in Fig. 18 through 24.

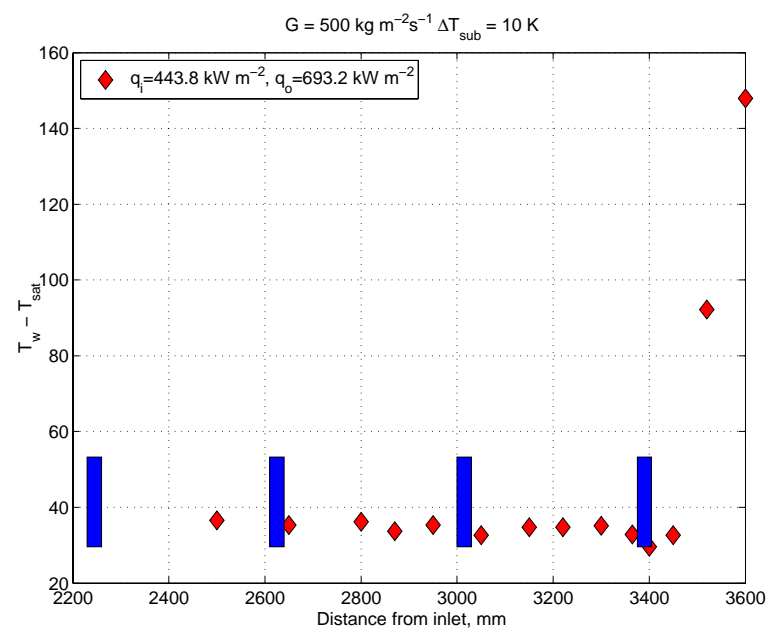

Figure 18. Tube wall temperature increase for $\mathrm{G}=500 \mathrm{~kg} \mathrm{~m}^{-2} \mathrm{~s}^{-}$ ${ }^{1}, \mathrm{p}=70$ bar and inlet subcooling $10 \mathrm{~K}$.

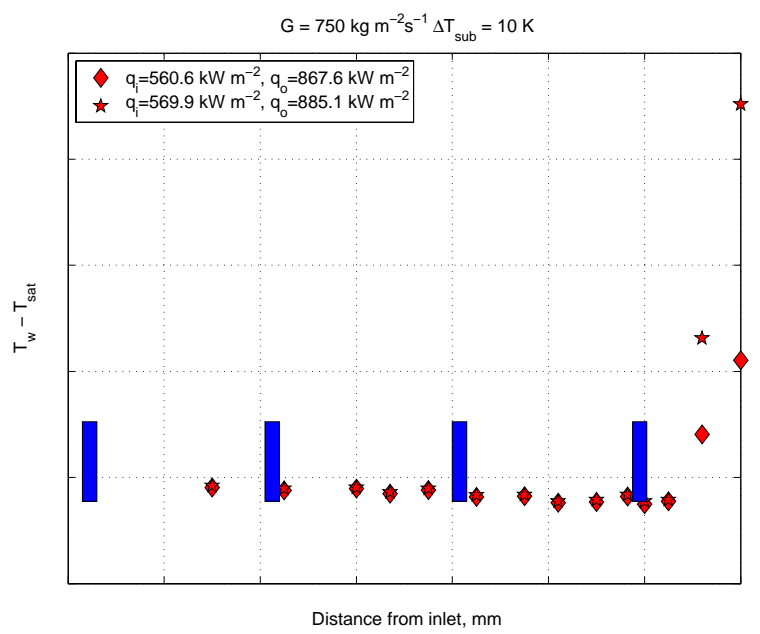

Figure 19. Tube wall temperature increase for $\mathrm{G}=750 \mathrm{~kg} \mathrm{~m}^{-2} \mathrm{~s}$ $1, \mathrm{p}=70$ bar and inlet subcooling $10 \mathrm{~K}$.

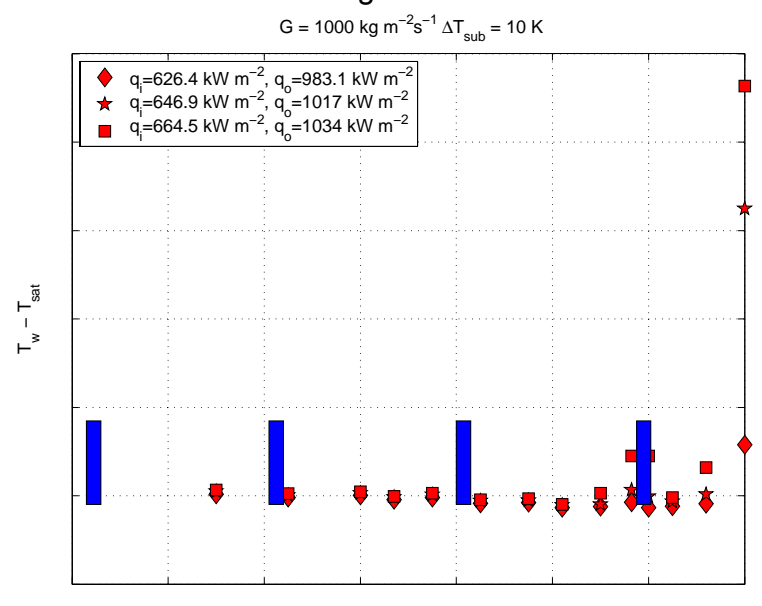

Distance from inlet, $\mathrm{mm}$

Figure 20. Tube wall temperature increase for $G=1000 \mathrm{~kg} \mathrm{~m}^{-2}$ $\mathrm{s}^{-1}, \mathrm{p}=70$ bar and inlet subcooling $10 \mathrm{~K}$.

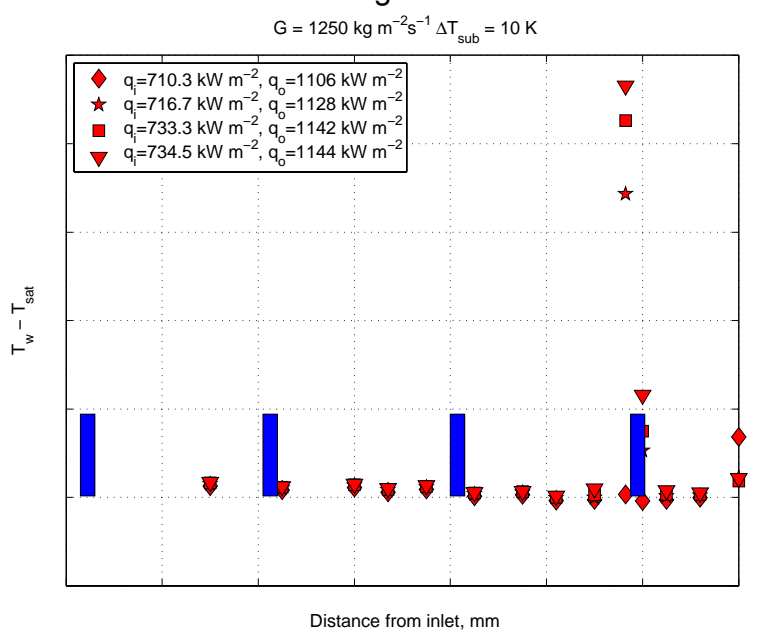

Figure 21. Tube wall temperature increase for $G=1250 \mathrm{~kg} \mathrm{~m}^{-2}$ $\mathrm{s}^{-1}, \mathrm{p}=70$ bar and inlet subcooling $10 \mathrm{~K}$. 


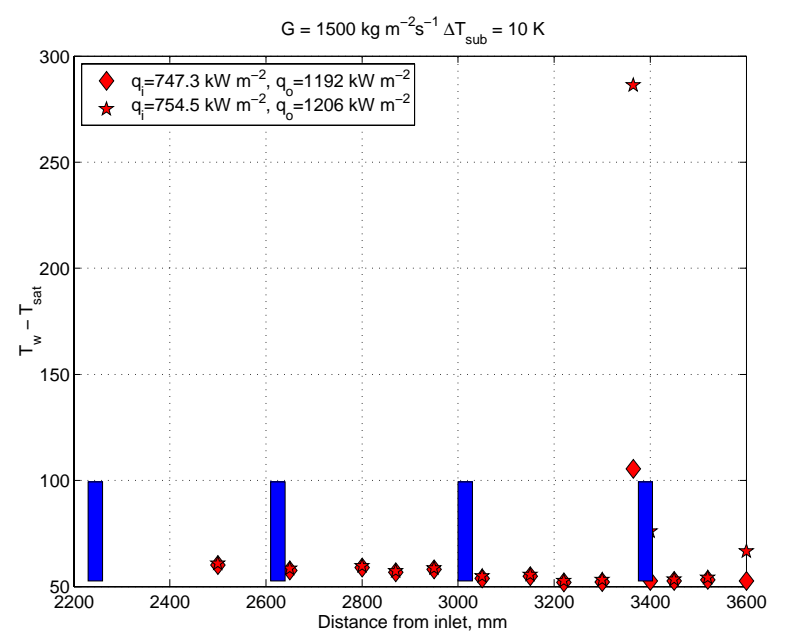

Figure 22. Tube wall temperature increase for $G=1500 \mathrm{~kg} \mathrm{~m}^{-2}$ $\mathrm{s}^{-1}, \mathrm{p}=70$ bar and inlet subcooling $10 \mathrm{~K}$.

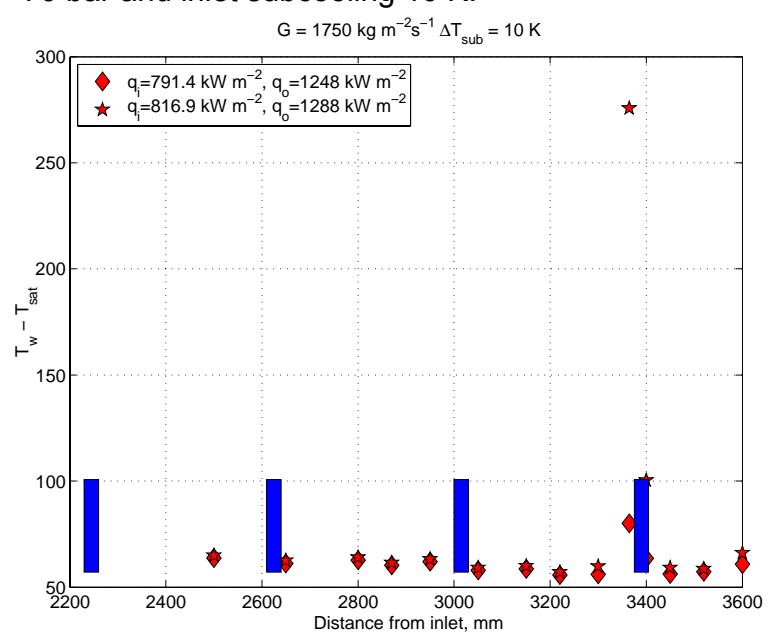

Figure 23. Tube wall temperature increase for $G=1750 \mathrm{~kg} \mathrm{~m}^{-2}$ $\mathrm{s}^{-1}, \mathrm{p}=70$ bar and inlet subcooling $10 \mathrm{~K}$.

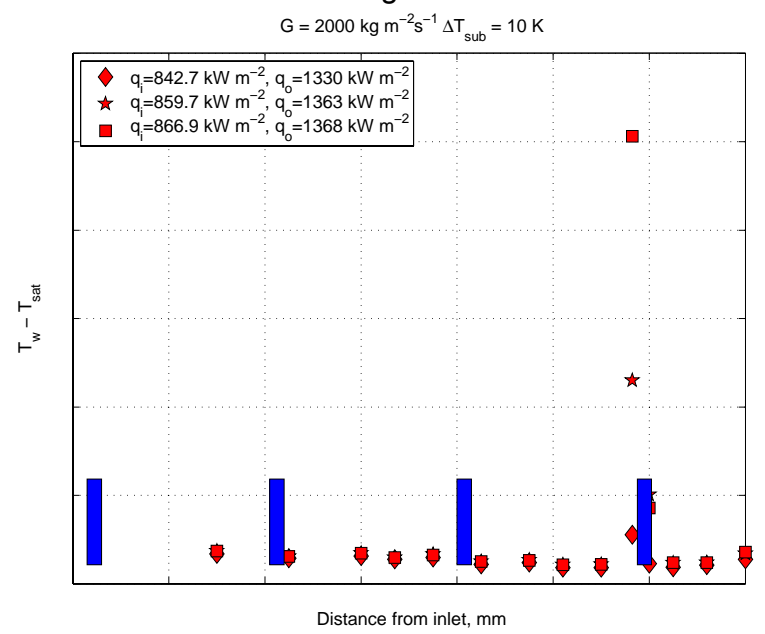

Figure 24. Tube wall temperature increase for $G=2000 \mathrm{~kg} \mathrm{~m}^{-2}$ $\mathrm{s}^{-1}, \mathrm{p}=70$ bar and inlet subcooling $10 \mathrm{~K}$.

\section{CONCLUSIONS}

Experimental investigation of the post-dryout heat transfer in an annulus with spacers indicates that the spacers have a significant influence on the local heat transfer conditions. This can be observed in e.g. Fig. 21 through 24, where postdryout patches that appeared upstream of the last spacer were effectively quenched.

The post-dryout patches are moved toward exit of the channel with decreasing mass flux. For the rod wall it can be seen by comparing Fig. 5 with Fig. 10. For low mass flux equal to $500 \mathrm{~kg} \mathrm{~m}^{-2} \mathrm{~s}^{-1}$ in Fig. 5, the post-dryout patch was shifted from the exit to upstream the last spacer (spacer number 7) when increasing the heat flux from 484 to 543.5 $\mathrm{kW} \mathrm{m}{ }^{-2}$. For high mass flux equal to $1750 \mathrm{~kg} \mathrm{~m}^{-2} \mathrm{~s}^{-1}$ in Fig. 10 , the post-dryout patch was shifted upstream the spacer number 6 when increasing the heat flux from 1050 to 1157 $\mathrm{kW} \mathrm{m}{ }^{-2}$.

The local equilibrium quality at dryout patch increases with decreasing mass flux. This is in agreement with general trends observed in dryout and post-dryout experiments in which the quality at dryout positions can achieve high values for low mass fluxes. Figure 17 shows the wall temperature increase versus equilibrium quality and it can be seen that points corresponding to low mass flux (circles) are located at high equilibrium quality values.

\section{ACKNOWLEDGEMENTS}

The financial support provided by SKI (Swedish Nuclear Inspectorate) is gratefully acknowledged. The authors are grateful to Westinghouse Electric Sweden AB for delivery of spacers used in present experiments.

\section{REFERENCES}

1. J. Blomstrand et al., Loop Studies Simulating - in Annular Geometry - The Influence of The Axial Power Distribution and The number of spacers on Dryout in 8x8 BWR Assemblies, 2nd Japanese-European TwoPhase Flow Group Meeting, University of Tsukuba, Japan, 25-29 September,2000.

2. P. Persson, Measurements and analysis of dryout in annular geometry with two-sided and one sided heating with uniform and non-uniform axial power and the influence of spacers and spacer positions, $40^{\text {th }}$ European Two-Phase Flow Group Meeting, Royal Institute of Technology, Stockholm, June 10-13, 2002.

3. K. Becker and A. Letzter, An experimental study of the effect of axial flux distribution on the burnout conditions in a $3650 \mathrm{~mm}$ long annulus, Report KTHNEL-21, 1974. 